\title{
Prospects of stem cell therapy in osteoarthritis
}

Osteoarthritis is a common disorder in which there is not only extensive degeneration but also an aberrant attempt at repair in joints. Stem cell therapy could provide a permanent, biological solution, with all sources of stem cells (embryonic, fetal and adult) showing some degree of potential. Mesenchymal stromal/stem cells, however, appear to be the leading candidates because of their ability to be sourced from many or all joint tissues. They may also modulate the immune response of individuals, in a manner influenced by local factors. This biological behavior of stem cells renders the application of regulatory standardizations challenging in comparison to pharmaceutical therapies. However, this would not be an issue if endogenous stem cells were activated to effect repair of an arthritic joint.

\section{KEYWORDS: articular cartilage bone immunomodulatory mesenchymal stem cell stem cell niches}

Osteoarthritis $(\mathrm{OA})$ is the most common form of arthritis and is estimated to affect 8.5 million people in the UK alone [201]. The disease brings about the ultimate destruction of synovial joints. For the patient, quality of life is reduced because of the loss of movement and function and, as the disease progresses, pain from the joint increases to become continuous, even occurring at rest. Underlying the disease is a loss of the normal homeostasis of the joint, generally leading to excessive catabolism relative to anabolism [1]. The arthritic joint can, however, demonstrate apparent repair mechanisms, although these often result in overactive but aberrant production of bone and cartilage in the form of osteophytes. OA was previously thought of as a 'wear and tear' process. More recently it has been defined, not as a single condition, but rather a common complex disorder with three groups of risk factors: genetic, constitutional (e.g., aging and obesity) and local (e.g., biomechanical consequences of joint injury, joint laxity or malalignment) [2,202] . OA is not simply a disease of cartilage destruction but a collection of different pathological processes involving several anatomical parts of the joint (Figure 1), with the relationship between the underlying bone and the cartilage being recognized in particular [3].

Different pathways may be involved at different stages of OA. For example, early in the disease, there is an initial increase in inflammatory mediators, matrix-degrading proteinases and stress-response factors in cartilage, perhaps in response to a mechanical injury [1]. After a compensatory attempt at repair, it appears that phenotypic modulation of the chondrocytes occurs, with abnormal matrix molecules being produced and altered cell behavior, resulting in a shift towards catabolism. It is becoming increasingly obvious that genetics has a much greater influence on the development of OA than previously understood, as evidenced in genomewide association studies [4], but the linkage to mechanisms often remains to be elucidated.

Why is there a need for new therapies to treat $\mathrm{OA}$ ? To date it is generally believed that there is little to be gained by surgical intervention before the end stage of disease, when arthroplasty can provide excellent pain relief and functional restoration. The problem with joint replacement is that the implants have a finite lifespan ( $10-15$ years) after which a variety of factors, such as wear particle formation, contribute to loosening and, therefore, the prosthesis is likely to require revision surgery. This is more comtreatment in the long term. The use of artificial joints in young patients (e.g., $<55$ years) is associated with higher failure rates when compared with older patients [5].

Current treatment options vary but in the UK there are national guidelines that concentrate on a holistic approach to the patient [202]. Management should include education and selfmanagement. Nonpharmacological measures are also recommended: exercise, manual therapy, weight loss and electrotherapy. Pharmacological management includes paracetamol and topical nonsteroidal anti-inflammatory drugs. Joint replacement is reserved for patients who have plex, costly and not as successful as the initial

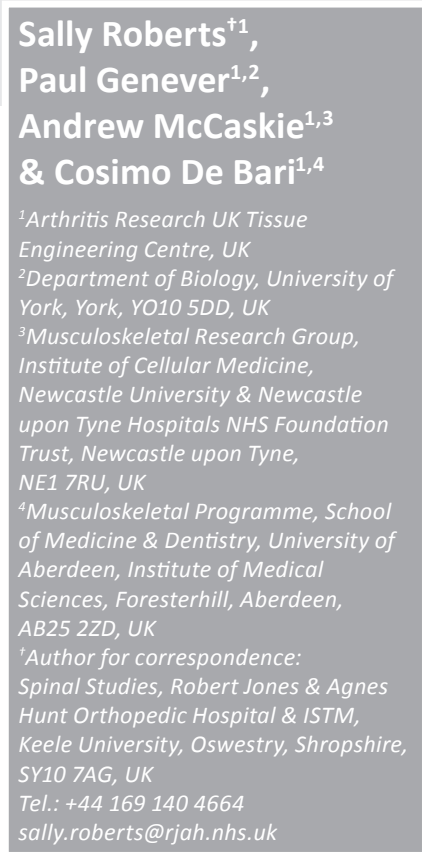

future ${ }_{\text {medicine }}^{\text {pind }}$ fsg 


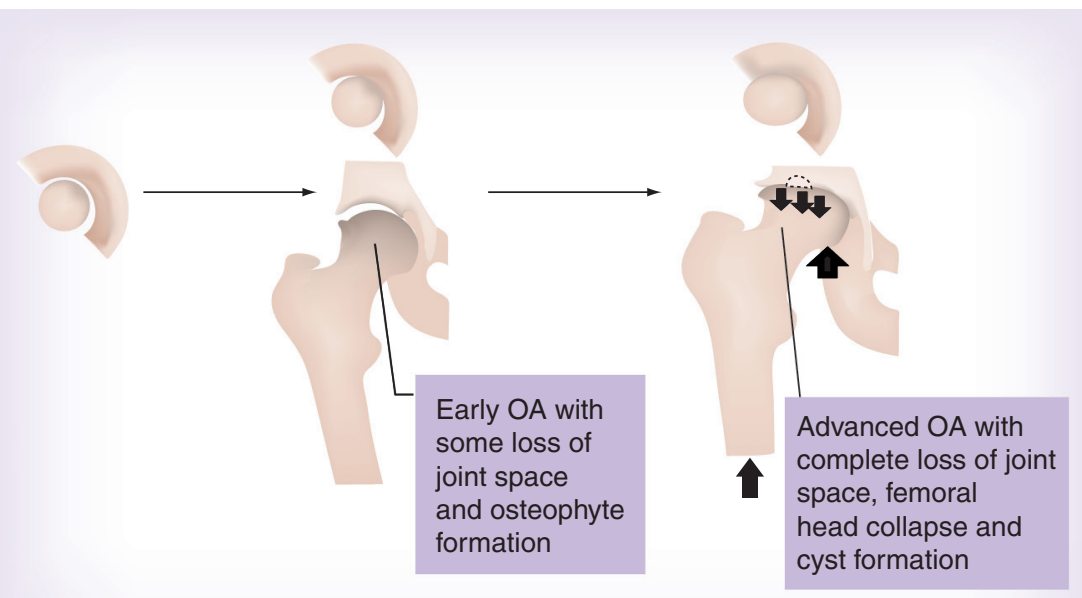

Regen. Med. @ Future Science Group (2011)

Figure 1. Changes in the ball and socket joint (e.g., the hip) in

osteoarthritis. Early in the disease the joint space is decreased due to loss of cartilage, but there is also new cartilage and bone formation as osteophytes, which form at the joint margins. In more advanced disease the joint destruction can progress to complete loss of joint space and changes in the shape of the bone that forms the ball and socket. In addition, there would be changes in the soft tissues that surround the joint such as the capsule and labrum.

OA: Osteoarthritis. and repair. Stem cell potency is often directly related to the developmental stage at which they first appear (FIgure 2). This includes totipotent stem cells in the early embryo following fertilization, pluripotent cells of the blastocyst's inner cell mass (ICM) and some fetal tissues, in addition to multipotent adult stem cells. Recent developments, however, suggest that this potency hierarchy is not unidirectional, with evidence that somatic cells can be reprogrammed to a more primitive phenotype and exist in an embryonic stem cell (ESC)-like state. Similarly, some adult stem cells may show more plasticity than previously believed and traverse lineage restrictions. What is clear is that stem cells of different origins and potencies hold significant therapeutic value in many clinical applications, including the treatment of arthritis.

\section{Embryonic stem cells}

Embryonic stem cells originate from the early embryo. Following fertilization and a few rounds of cell division to form a spherical morula, ESCs exhibit totipotency, having an ability to differentiate into all the cells required to develop into a viable organism, including supportive tissues such as the placenta and umbilical cord. Further rounds of cell division lead to the formation of a blastocele cavity containing an ICM of pluripotent stem cells with an outer layer of trophectoderm, from which the extra-embryonic tissues develop [7]. Through its pluripotent capacity, the ICM develops into the three embryonic germ layers: ectoderm, endoderm and mesoderm, which ultimately give rise to the embryo. Consequently, the ICM represents a valuable source of ESCs for research and therapeutic applications. ESCs were first isolated from mouse embryos in 1981 [8,9], and later from human embryos [10], with the first human ESC line established in 1998 [11]. These cells proliferate extensively in vitro and maintain expression of primitive ESC markers, with a normal karyotype. Implantation into severe combined immunodeficiency mice resulted in the formation of teratomas, which are characterized by a repertoire of cell and tissue types from all three germ layers, indicative of pluripotency [11].

The precise mechanisms that control pluripotency are not fully understood. However, a triumvirate of transcription factors, Oct-4, Nanog and Sox2, appear to act cooperatively to regulate target gene expression, prevent differentiation and maintain stem cells in a pluripotent state [12-15]. 
Epigenetic factors also regulate pluripotency. ESC differentiation is accompanied by a shift in the chromatin state from a transcriptionally permissible open euchromatin to a more restrictive heterochromatin [16-18]. Gene silencing by DNA methylation is also associated with ESC differentiation [19] and miRNAs, a large family of small noncoding RNAs that regulate protein translation, have also been implicated in ESC maintenance [20,21]. The ability of ESCs to undergo seemingly endless rounds of cell division is at least in part due to their high levels of telomerase activity. This enzyme acts to maintain the length of telomeres, which are present at the ends of chromosomes and are lost during mitosis. In somatic cells, unrestricted telomere loss leads to replicative senescence. The high levels of telomerase in ESCs re-establishes telomere length, permitting prolonged periods of self-renewal, which is downregulated following differentiation $[11,22,23]$.

\section{Fetal stem cells}

Non-ESCs are present in fetal tissues and fetalderived extra-embryonic tissues. Umbilical cord blood-derived hematopoietic stem cells have been used extensively in transplantation therapies for a number of years to reconstitute hematopoietic activity following treatment for leukemias and related disorders [24], and provide examples of successful stem cell-based therapy [25]. More recently, other stem cell populations of fetal origin have been isolated, with most attention focusing on MSCs, which have been identified in various fetal tissues including the spine [26], bone marrow, blood, liver, lung and kidney [27], as well as the umbilical cord, placenta, Wharton's jelly, amniotic fluid and amniotic membranes [28,29].
Fetal MSCs have characteristics similar to MSCs derived from adult tissues (see later), including their plastic adherence and cell surface marker expression. They are described as being at least partially differentiated cells but retaining high expansion, regeneration and low immunogenic properties. There is also evidence that fetal MSCs express markers associated with ESCs (Oct-4, Nanog and SSEA-4) suggesting a more primitive phenotype [27] but do not show tumorogenicity in vivo [30].

\section{- Induced pluripotent stem cells}

Uncovering the mechanisms that control pluripotency has led to some remarkable developments in the stem cell field. The introduction of different combinations of factors to somatic cells initiates a reprogramming pathway that appears to reset their developmental clock to a more primitive state so they take on characteristics similar to ESCs. These induced pluripotent stem (iPS) cells were first reported in mouse somatic cells in 2006 using combinations of the transcription factors Oct-4, Sox2, Klf4 and c-Myc [31]. This work was later reproduced in human somatic cells using the same factors $[32,33]$ as well as combinations of Oct-4, Sox2, Nanog and LIN28 [34]. Human iPS cells proliferate extensively in culture whilst maintaining pluripotency; they form teratomas in vivo and give rise to viable embryos when injected into blastocysts [32-34]. These characteristics suggest that iPS cells may be used to generate therapeutically valuable, patient-specific cell types, without the need to generate and/or destroy human embryos. However, challenges remain. For example, reprogramming efficiency is low, concerns surrounding teratoma formation remain and there is evidence that iPS cells retain

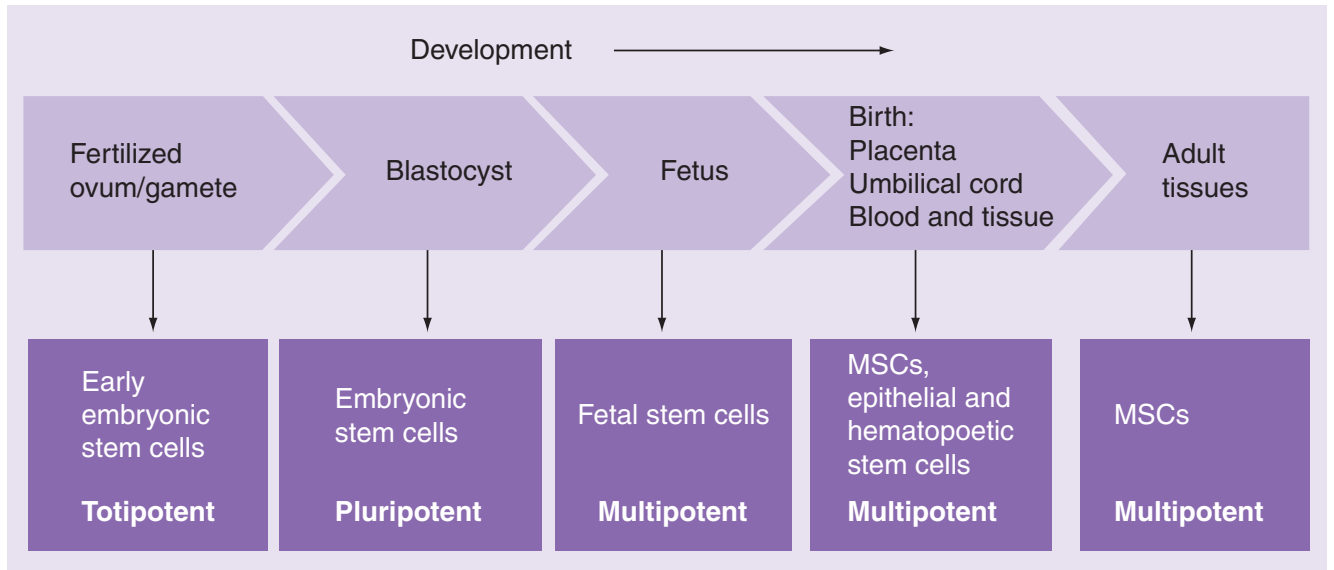

Figure 2. Stem cells obtained at different stages of development can have varying levels of potential for differentiation.

MSC: Mesenchymal stem cell. 
epigenetic characteristics of the parent somatic cell [35]. Three different experimental systems of inducing pluripotency have all demonstrated genomic aberrations in induced stem cells [36]. However, work to overcome these hurdles is currently being addressed, such as using alternate transcription factors other than c-Myc (as this appears to promote genomic instability [36]) or alternate ways of transformation [37-40].

\section{Adult stem cells}

Stem cells are located in a range of adult tissues where they contribute to tissue homeostasis, repair and regeneration. Compared with ESCs, adult stem cells have a more restricted (multipotent) differentiation capacity, generally giving rise to cell types of the resident tissue. Adult stem cells are also prone to replicative senescence, with low or absent telomerase activity levels, which is insufficient to prevent telomere loss [41]. Adult stem cells are believed to be located in vivo in a specialized microenvironment, or niche. This niche provides the appropriate 3D supportive surroundings to maintain stemness, quiescence and survival, whilst permitting the cells to exit the niche, and proliferate and differentiate following exposure to certain induction stimuli [42]. Adult stem cells offer several advantages for autologous and allogeneic therapies, including ease of derivation, tissue-specific differentiation potential, extensive but controlled proliferative activity, safety (lack of teratoma formation) and fewer ethical constraints than for embryonic cells. For cell-based treatments for arthritis, MSCs appear to be the leading candidates.

\section{Mesenchymal stem cells}

Friedenstein and colleagues first identified the stem cell potential of bone marrow stroma as an adherent population of colony-forming unit fibroblasts [43]. In the decades that followed, numerous efforts have been made to characterize these cells, which today are commonly termed MSCs [44], and although 'multipotent (mesenchymal) stromal cells' and 'skeletal stem cells' may be biologically more accurate descriptions [45,46], the MSC acronym persists. Bone marrow-derived MSCs have received most attention, although they have been isolated from numerous adult tissues, including the liver, spleen, muscle, brain, thymus and lung [47]. They share common characteristics, being plasticadherent fibroblast-like cells with tri-lineage potential to differentiate into chondrogenic, osteogenic and adipogenic cell types [48]. The differentiation capacity, relative ease of isolation and ex vivo amplification have made MSCs attractive candidates for both research and therapeutic applications, often focused toward orthopedic interventions. However, there are still aspects of MSC biology, such as their cellular identity and location in vivo, that remain unclear.

\section{MSC characteristics}

\section{\& differentiation potential}

As suggested by the debate over their name, MSCs are somewhat enigmatic cells, lacking clear definition or universally adopted selective markers for their identification and isolation. Plastic adherence is often the selection method of choice, invariably delivering a heterogeneous cell population, although single-cell cloning strategies can give rise to MSC lines. Positive and negative expression of a panel of nonselective cell surface antigens is often used to identify MSC populations. MSCs are defined in vitro as being positive for $\mathrm{CD} 29$ ( $\beta 1$-integrin), CD44 (H-CAM, hyaluronan receptor), CD73 (SH3/SH4, ecto-5'-nucleotidase), CD90 (Thy1), CD106 (VCAM-1), CD105 (SH2, endoglin) and CD166 (SB-10, ALCAM), whilst lacking expression of hematopoietic markers, such as CD34, CD 45 and CD14, and HLA class II [48,49]. MSCs also express the antigen recognized by the Stro-1 antibody [50], although the cognate cell surface protein is unknown. More recent work has led to the identification of the low-affinity NGF receptor (LNGFR)/CD271 [51] and CD146 [52] as leading MSC marker candidates.

Mesenchymal stem cells typically differentiate into stromal cells of skeletal tissues: bone, cartilage and fat (Figure 3). However, there is evidence that MSCs are more plastic than initially believed and can transdifferentiate into nonskeletal tissues, including liver, pancreas and neural cells. Although the plasticity of MSCs remains a matter of some debate, the reprogramming technology used for iPS cell generation does suggest that MSCs may be deployed in broader tissue-specific differentiation protocols [53]. Considering the potential role of MSCs in arthritis therapy, osteogenic and chondrogenic differentiation will be briefly reviewed here.

During osteogenesis, MSCs mature through a series of intermediates, from primitive stem cells to committed osteoprogenitors, preosteoblasts and mature, differentiated osteoblasts, accompanied by matrix accumulation and mineralization. The different stages of osteogenic differentiation are regulated by a network of locally acting and systemic signaling pathways that influence gene expression profiles and cell behavior. At the 


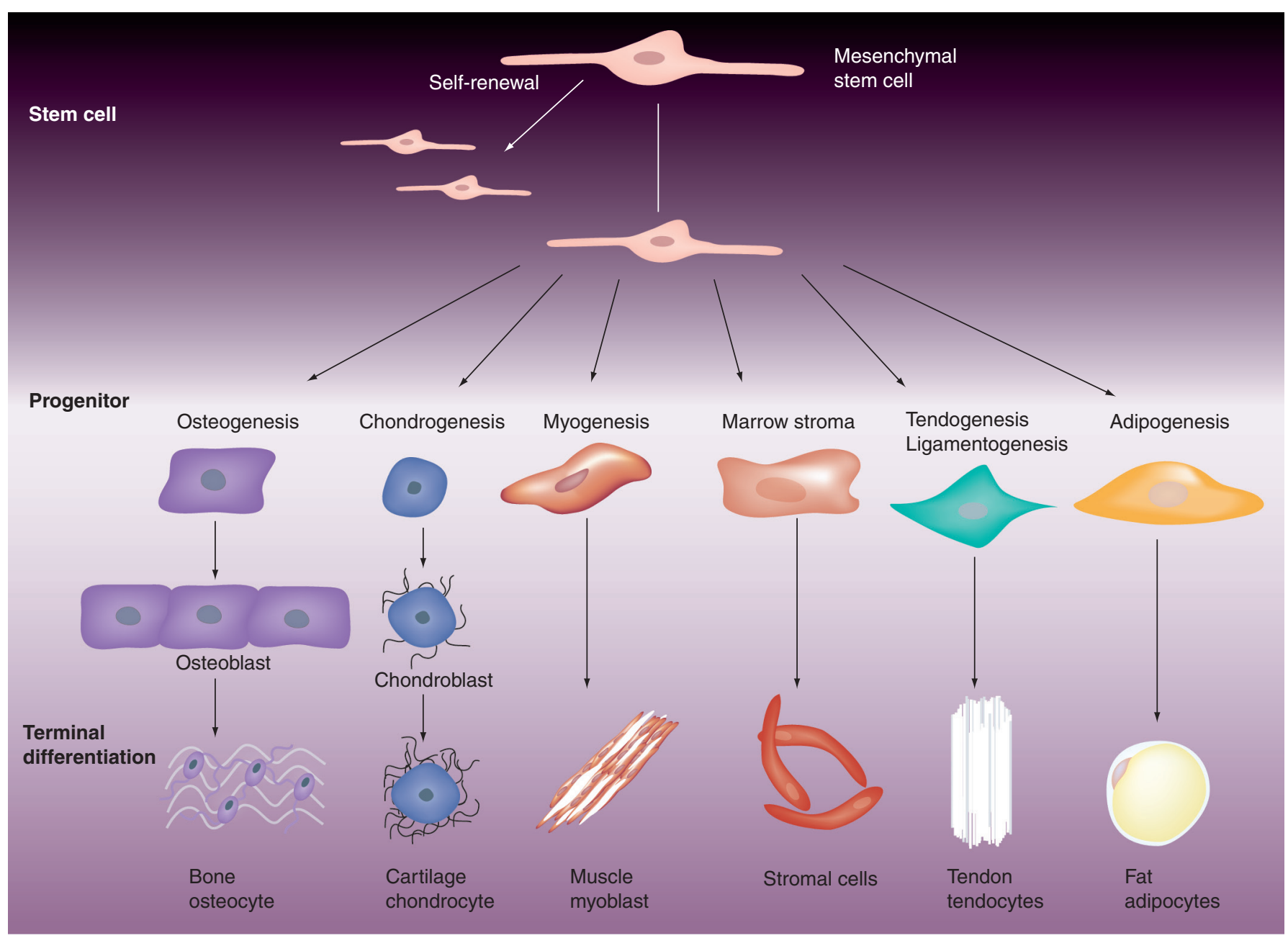

Figure 3. Multilineage differentiation potential of mesenchymal stem cells. Mesenchymal stem cells are able to undergo several rounds of cell division prior to differentiation into a range of mesenchymal cell types, including bone, cartilage, muscle, stroma, tendon and adipose.

Adapted with permission from [144].

transcriptional level, osteogenesis is regulated by a number of factors, primarily Runx 2 and Osterix, which can direct MSCs towards an osteogenic fate by targeting the expression of bone-associated proteins, including type I collagen, bone sialoprotein, osteopontin and osteocalcin [54]. In vitro, lineage-specific differentiation of MSCs can be promoted following exposure to a simple cocktail of induction stimuli over several days. For osteogenesis, these frequently included combinations of ascorbic acid, dexamethasone and $\beta$-glycerophosphate [55]. The extent of osteogenic differentiation can be monitored over time by expression profiling firstly of osteogenic markers, such as Runx 2 expression and increased alkaline phosphatase activity, and then in the later stages, production of osteopontin, osteonectin and osteocalcin [54].

Chondrogenic differentiation is similarly influenced by a complex array of different signaling and transcriptional networks. The transcription factor, Sox9, has a key role in directing chondrogenesis in MSCs [56], and both Runx2 and Sox9 can regulate each other's transcriptional activity [57,58] to assist in the osteochondrogenic specification of MSC fate. Sox 9 can act cooperatively with Sox 5 and Sox 6 to drive expression of extracellular cartilage matrix proteins, including collagens type II, IX and XI, and aggrecan, with type X collagen expressed in mature hypertrophic chondrocytes [54]. In vitro, chondrogenic differentiation of MSCs is often induced by high cell density micromass or pellet culture in a serum-free medium supplemented with TGF- $\beta$.

\section{Immunomodulatory role of MSCs \\ \& homing}

There is increasing evidence that MSCs can influence the immune system. They have been attributed with immunosuppressive effects to the point that they are being trialed in humans as therapy for graft-versus-host disease and Crohn's 
disease (reviewed in [59]). However, their mechanisms of action in this area are poorly understood [60] and there is even some evidence that they may not always act to reduce the immune response. Immunosuppressive properties of MSCs from various sources (including umbilical cord MSCs [61]) have been demonstrated in vitro via their inhibition of both lymphocyte proliferation and reduced production of proinflammatory cytokines $[60,62]$. They also inhibit antibody production by $\mathrm{B}$ lymphocytes and inhibit the activity of dendritic antigen presenting cells. There is also similar evidence from some in vivo studies, where they have been shown to reduce graft-versus-host reaction, prolonging skin and heart allograft survival [63,64].

However, there are other in vitro studies indicating opposite properties with evidence that MSCs can lead to an inflammatory response via prostaglandin production, for example PGE2 [65]. PGE2 has been demonstrated to promote immune inflammation via its effect on the T-cell population [66]. In other studies PGE2 is reported to actually mediate immunosuppressive effects of bone marrow and adipose-derived MSCs, at least when cultured together with dendritic cells [67]. MSCs themselves have a low immunogenic phenotype, expressing low levels of HLA molecules (although this can possibly be altered in response to varying levels of proinflammatory cytokines). Hence, in vitro, they do not elicit a $T$ lymphocyte response. However, there is evidence that they can cause an immunogenic response in vivo, in both mice and rats, in response to allograft skin grafts [68], particularly under inflammatory conditions. These actions/activities of MSCs may be elicited by either chemical or paracrine effects or alternatively via cell-cell contact, or even by both mechanisms.

Thus, MSCs may have dual immunomodulatory capacity [60]. The exact nature of the response appears to depend on local conditions, where other factors, such as the level of IFN- $\gamma$ or TNF- $\alpha$, may determine the ultimate situation. Hence the resulting balance of whether the influence of MSCs is immunosuppressive or inflammatory may be a reflection of the environment that they are in. Also of relevance to MSC activity is their ability to secrete various modulating factors that could help the repair of tissues. For example, MSCs modulated the phenotype of cardiac fibroblasts and their ability to degrade extracellular matrix, hence accounting for the significant decrease in ventricular fibrosis following intracardiac injection of MSCs in a rat model of postischemic heart failure [69].
Another property attributed to MSCs, which is relevant to tissue repair, is their ability to migrate and 'home' or engraft to an area of tissue damage in a similar manner to leukocytes homing to sites of inflammation. Homing involves a series of events beginning with cell tethering, rolling and, via contacts with endothelial surfaces, a chemokine-triggered integrin activation, allowing production of adhesion molecules and extravasation $[70,71]$. The production of adhesion molecules is very significant in terms of tissue engineering if it permits the attachment of mobile cells and may be a route for infused MSCs 'homing' and attaching at the site of injury. The exact mechanisms underlying homing and engraftment of MSCs remain to be elucidated and they may be at least in part a stochastic event or explainable with the vasodilatation and increased blood supply to the injured tissues.

\section{Endogenous joint stem cell niches}

Articular cartilage is commonly regarded to have limited capacity for intrinsic repair. However, structural restoration of joint surface integrity after osteochondral lesions has been documented in humans [72-74], while spontaneous repair has been reported in animal models of full-thickness joint surface injury $[75,76]$. These data suggest the possibility of intrinsic repair mechanisms via recruitment of endogenous stem cells. In this regard, a recent proof-of-concept study in rabbits demonstrated the regeneration of the entire articular surface of the synovial joint without cell transplantation [77]. Rather it appears that the repair was mediated totally by host endogenous cells, potentially derived from the synovium. Even allowing for the recognized difference in growth and repair rates between species such as rabbit and humans, this paper provides encouraging indications of inherent repair mechanisms. It suggests that pharmacological manipulations of the joint environment, to target endogenous stem cell niches and reparative signaling pathways, have the potential to form a cell-free therapeutic option for joint resurfacing.

\section{Native stem cells \& joint homeostasis}

Many joint tissues contain cells that, after enzymatic release and in vitro culture expansion, display properties of MSCs. Originally discovered in bone marrow [43], MSCs have been isolated from synovial fluid [78] in addition to most connective tissues, including synovial membrane [79,80], periosteum [81-83], intervertebral disc [84] and adipose tissue [85]. In adult articular cartilage there are highly clonogenic multipotent cells [86], 
which appear resident in normal human cartilage, as reported by Williams et al. who isolated them from individuals aged between 10 and 57 years [87]. Therefore, the joint environment is rich in progenitor/stem cells but our understanding of their anatomical location in apposite niches and the molecular regulation of their functions is very limited. The lack of specific cell-surface markers has, in the main, impeded the direct identification of the MSCs in their native tissues. In bone marrow, it has been suggested that MSCs harbor in perivascular areas [88], where they could be in close proximity to hematopoietic stem cells, which contribute to maintaining their quiescence [89].

Pericytes are cells located on the abluminal side of small blood vessels and are juxtaposed to endothelial cells. It has been suggested that pericytes may be the native MSCs in vivo, which would explain their presence in most connective tissues. The proximity to vessels would make it easy for pericytes to enter the bloodstream and migrate to sites of injury [90]. However, this notion is challenged by the fact that MSC-like cells have also been isolated from articular cartilage $[86,87,91]$, notoriously an avascular tissue. Chondrogenic progenitor cells have been found in late-stage osteoarthritic cartilage, which interestingly increases their chondrogenic behavior in vitro in response to estrogen and testosterone $[92,93]$. Similarly, stem cells appear to be resident in another primarily avascular tissue, the intervertebral disc [84]. In addition, whilst pericytes may give rise to MSCs, it is also possible that pre-existing local committed progenitors are recruited to a pericyte fate, as shown in vivo with bone marrow MSCs [52]. In this regard, it has to be considered that the term 'pericyte' is an anatomical description of a cell that is abluminal and that pericytes are not a lineage themselves. Their developmental origins are not clear and it is likely that, rather than a common ancestor, pericytes have distinct ontogeny and biological properties that are related to their tissues of residence.

The fat pad of the joint has been identified as a further source of stem cells for repairing the osteoarthritic knee joint [94]. These multipotential cells isolated from osteoarthritic knees of elderly individuals retained their chondrogenic capability after extensive culture expansion. Adiposederived stem cells are comparable to MSCs in most properties but they are reported to be easier to harvest and to obtain in larger numbers $\left(2-6 \times 10^{8}\right.$ in $300 \mathrm{ml}$ of adipose tissue obtained by liposuction), and with a faster proliferation rate than bone marrow-derived MSCs [95].
Recently, a double nucleoside labeling scheme in a mouse model of cartilage surface injury in a knee joint was utilized to identify a population, in vivo in the adult synovium, of long-term label-retaining cells [76]. These slow-cycling cells proliferated and differentiated into chondrocytes after injury, hence displaying typical features of stem cells [96]. The identified cells were nonhematopoietic, nonendothelial, stromal cells with a MSC-like phenotype, and were distinct from pericytes [96].

The knowledge of the mechanisms underlying joint surface homeostasis and repair in health and disease will result in the development of novel therapeutic interventions to modulate MSC niches pharmacologically to promote joint surface regeneration and influence outcomes of joint disorders such as $\mathrm{OA}$, with the ultimate goal to restore joint homeostasis. It may be possible in the future to shift stem cell niche activity in the joints of patients with OA from the deranged program underlying chondro-osteophyte formation to an effective repair of injured joint tissues, thus preventing the establishment of end-stage OA.

\section{Cell therapy with exogenous stem cells}

Cell therapy started being used in the orthopedic clinic with a technique for repairing cartilage damage developed by Brittberg et al. [97] who used autologous cells, primarily chondrocytes, some of which may have been chondroprogenitors or stem cells [98]. Subsequently autologous disc cells have been used as cell therapy for treating herniated intervertebral discs [98] or MSCs for nonunion bone fractures [99]. These cells are removed from the patient, isolated and culture expanded prior to reimplantation. At this stage they may be injected or applied directly to the injured or diseased joint [97-101] or, alternatively, applied in combination with a scaffold. For cartilage repair this could be a hyaluronan gel [102], or any one of several collagen preparations $[103,104]$ or other scaffolds, such as fibrin mixed with a synthetic polymer (polyglycolic/polylactic acid and polydioxanone; Bioseed ${ }^{\circledR}$ ) [105]. The culture expansion of autologous cells serves a useful purpose in minimizing the amount of tissue or cells that must be removed from the patient whilst providing an increased number of cells for eliciting repair once implanted. However, it is not without its problems. In addition to the potential dedifferentiation, as discussed elsewhere, it is limiting in terms of increasing the cost considerably and also rendering it a two-stage procedure. Establishment of a bank of allogeneic cells could 
alleviate the need for autologous cells at all in the clinic. The other alternative is to utilize scaffolds with chemoattractant molecules incorporated, which can attract and activate endogenous stem cells to the area, such as has been used in the rabbit models [77].

Since OA also involves the bony component of the joint, tissue engineering strategies involving scaffolds suitable for repair or regeneration of bone are also very important and relevant. Warnke et al. successfully tissue engineered a mandible for a carcinoma patient by utilizing a scaffold of bone mineral blocks into which they placed autologous bone marrow in addition to BMP7 in a collagen gel [106]. This case report is very interesting in that the scaffold was then placed into the patient's latissimus dorsi muscle for 7 weeks before transplanting to the correct site in the jaw. Hence this is an example of using the patient's own body as a bioreactor, allowing the application of multiple environmental factors that are likely to be optimal for growth, for example, autologous growth factors and appropriate levels of mechanical stimuli.

Another interesting case report is that of Macchiarini et al. who describe the use of decellularized cadaveric tissue as a 'natural' scaffold [107] In this particular case it was a section of trachea that was seeded with autologous epithelial cells together with bone marrow-derived MSCs, which had been grown in chondrogenic differentiation medium for 72 h. Following $96 \mathrm{~h}$ in a bioreactor in vitro, the tissue engineered cartilaginous construct was implanted into the bronchus to replace a tuberculous bronchus of the patient. The treatment was highly successful as it went on to develop a fully functional tissue and led to the complete recovery of the patient.

The use of an appropriate scaffold is likely to be all important in orthopedic tissue engineering just as in other specialities. It can provide many different forms of cellular cues, from topographical to chemotactic to growth factors. Therefore, it can dictate the population of cells that will occupy it, as well as direct their activity. There are various developments ongoing in the field of OA, attempting to develop multiphase scaffolds that can mimic osteochondral structures, encouraging both cartilage and repair within one scaffold.

\section{Bioprocessing \& regulatory aspects Standardization of bioprocessing}

In cell therapy, cells are dynamic entities that produce growth factors and cytokines, and these pose unprecedented challenges in the bench-to-bedside standardization path towards clinical application.
Traditional pharmaceutical concepts and protocols cannot be directly extrapolated to develop a cell-based medicinal product. Pharmacological properties such as pharmacokinetics and shelf-life of the cellular product as well as product identity specification, mode of action, potency assessment and side effects are complex but need to be addressed for routine, large-scale clinical use of cell therapy.

There is therefore a need for standardized and robust bioprocessing protocols in order to manufacture reliable cellular products with known potency. Autologous cell therapies, such as autologous chondrocyte implantation (ACI), add an increased level of complication, where patient-related factors, including comorbidities, are likely to further influence the properties of the cell preparation. Hence, the quality of the cellular products needs to be assured even if the entire bioprocessing is well standardized [108].

It is known that in vitro culture expansion of articular chondrocytes causes their dedifferentiation with loss of their intrinsic capacity to form hyaline cartilage in vivo [109]. Indeed, in some patients the repair tissue after ACI is fibrocartilage [110]; this could be due to varying degrees of loss of the phenotype of the expanded chondrocytes during in vitro culture. To tackle this problem, a nude mouse assay was developed to assess the potency of adult human articular chondrocytes when injected intramuscularly to generate stable hyaline cartilage, resistant to vascular invasion and endochondral ossification [109]. By linking the phenotype of chondrocytes prior to intramuscular injection to the outcome of ectopic cartilage formation in the nude mouse, a set of molecular markers predictive of stable cartilage formation was identified [109]. The scoring system of cartilage-forming potency was further refined over time and was used to develop a quality-controlled chondrocyte product for ACI. In a randomized clinical trial, compared with microfracture, 'characterized' chondrocyte implantation for the treatment of articular cartilage defects of the femoral condyles of the knee resulted in tissue repair, which at 12 months was superior to that after microfracture [111]. Notably, although clinical outcome at 1 year was similar for both treatments, characterized chondrocyte implantation resulted in significantly better clinical outcome at 36 months [112], suggesting that a superior structural outcome may lead to improved long-term clinical benefit.

However, the difficulty in culture expansion of chondrocytes, which are unstable and rapidly lose their phenotype [109], and the use of autologous cell 
preparations make scale-up an extremely difficult task. MSCs are easily accessible, culture-expandable and chondrogenic. Hence, their use in place of chondrocytes is intensely advocated. Their alleged immune privilege and immunomodulatory properties [113] could also allow the production of large batches of certified cell preparations, available off the shelf and ready for allogeneic implantation. In addition, MSCs may be amenable to resurfacing of eburnated joints in patients with OA. For these reasons, the use of MSCs for joint surface repair is being explored in humans. Wakitani et al. treated 12 patients with knee OA with MSCs on a collagen gel in a similar manner to the standard ACI procedure [114]. Tissue regeneration was better at 42 weeks in this group than the control group with no cells applied.

Mesenchymal stem cells have the capacity to differentiate into chondrocytes. However, the induced chondrocyte-like phenotype may not be retained after in vivo implantation [115]. In addition, the MSC-derived cartilage-like tissue may not be resistant to endochondral ossification. There is evidence that the cartilage-like tissue formed in vitro can be transient and destined to be at least partly replaced with bone via endochondral ossification [116,117]. Nevertheless, it is possible that the environment of a cartilage defect may be able to promote and stabilize a hyaline cartilage phenotype. Ultimately, preclinical and clinical studies will be needed to compare MSCs with articular chondrocytes in an ACI procedure.

The growing body of evidence from comparative studies on human MSCs from multiple tissues indicates that MSCs have distinct biological properties that are dependent on their tissue of origin. Whether these are imprinted in genetic and epigenetic factors through developmental ontogeny or result from environmental cues remains to be elucidated.

Hence, the MSC is not a unique cell type in terms of function and potency, and this of course has implications in the choice of the adequate MSC type for clinical applications and poses particular challenges for establishing appropriate 'markers' for definition and monitoring by regulatory authorities. Of note, the definition of MSCs based on: their ability to attach to plastic; a specific cell surface molecular profile with cells being positive for CD73, CD90, CD105 and negative for CD34, CD45, HLA-DR, CD14 or CD11b, CD79a or CD19; and the potential to undergo osteogenesis, chondrogenesis and adipogenesis [49], which perhaps is valid for research purposes, appears clinically inadequate. For instance, MSCs from human periosteum displayed a significantly greater bone-forming potency than MSCs from matched human synovium, despite both MSC populations having similar phenotypes [118]. Another study compared human MSCs from synovium, periosteum, bone marrow, adipose tissue and muscle and identified synovial MSCs as superior chondroprogenitors [119]. Tissue of origin is not the only source of variability as there are many other factors, including donor-related variables, which need to be taken into account. In addition, single cell clonal heterogeneity is present within the MSC population derived from the same tissue source $[120,121]$, suggesting the existence of multiple functionally distinct MSC subsets within the same tissue. There is therefore a need to identify marker sets that allow purification of prospective MSC subsets with a consistent and reproducible tissue-forming potency. This may allow development, for specific clinical indications, of one-stop protocols whereby the MSCs with the desired potency can be purified in the theater and transplanted straight back into the patient, without the requirement for in vitro manipulations and culture expansion. The use of minimally manipulated autologous cell preparations would greatly simplify the regulatory path towards a clinical grade product.

\section{Regulatory issues}

The regulatory framework covering biological medicinal products, which incorporate human tissues or cells or tissue engineered products, has been evolving over the last decade $[122,123]$. The European Commission, via the European Medicines Agency (EMA), has produced a series of Directives on Advanced Therapy Medicinal Products (ATMP). The EMA/Committee for Medicinal Products for Human Use (CHMP)/410869/2006 lays down general guidelines that are applicable to cellbased medicinal products. The Committee for Advanced Therapies (CAT) and the Biologics Working Party (BWP) have subsequently produced further guidance with reflection papers on both cartilage repair and stem cell-based medicinal products as human embryonic and fetal cells were not previously covered by the regulatory dictates [124]. The reflection paper on stem cellbased medicinal products, which was released in March 2010 [203], covers iPS cells, hESCs and adult-derived MSCs. The authors take a pragmatic stance and recognize that, while stem cells may be the starting material, the final products may be terminally differentiated cells derived from these stem cells, or they could even be a mixture of cells with varying profiles. 
Thus, while all manufacturing must adhere to good manufacturing practice rules as for other products, stem cells are not a homogenous class of medicinal products but rather represent a spectrum for which there is a variable degree of scientific knowledge. As such, they recommend that a risk-based approach to the use of stem cells is used [203]. Therefore, it is likely that the regulatory view will continue to evolve along with stem cell science and clinical experience with stem cell-based products.

\section{Hopes \& fears of stem cells in the treatment of OA}

The impression that stem cells have the capability to produce all cell types in an unlimited fashion, particularly ESCs, has been a driving force for interest and research into their use for regenerative medicine. This has raised great expectations in the minds of the public for all branches of medicine including orthopedics. Added to this, the advent, in the last 5 years, of iPS cells and the ability to transform adult stromal cells to cells of near ESC capability demonstrates both how quickly the field can change [125] and also how little we fully understand about the basic biology of stem cells. The more recently observed immunomodulatory effects that stem cells, such as MSCs, have (albeit also incompletely understood) is another potential advantage and could have widespread benefit to the more inflammatory arthritic diseases such as rheumatoid arthritis. This may actually prove to be as important as the direct reparative cell therapy benefits if it results in diminishing or eradicating inflammation in the joint in degenerative joint diseases or can attract the correct native cell population to the appropriate site.

Cell therapy using autologous cells would obviously be of limited use in treating genetic disorders, where allogeneic or xenogeneic cells could be more useful. There is increasing evidence for genetic influence in degenerative joint diseases, such as OA [126,127] and disc degeneration $[128,129]$. This may render autologous cell therapy inappropriate in some individuals as all cells will obviously have the same genetic makeup. This would not be the case where there is local aberrant repair or lack of homeostasis, such as appears to be the case in nonunion bone fracture patients with MSCs from the site of the nonunion expressing excessive amounts of the antagonist of Wnt signaling, Dkk-1, which is associated with poor bone osteogenesis [130]. Indeed, in such patients autologous MSC treatment appears to be effective [99].
Another concern regarding autologous stem cell therapy is that of the quality of the cells available for repair. For example, might stem cells from older OA patients (whether culture expanded or endogenous locally sited cells) show high levels of senescence and/or reduced proliferative capacity? There are some studies suggesting this to be so with a reduced proliferation capacity of MSCs from older individuals [131] or lower chondrogenic capability of those from older patients with advanced OA being reported [132]. However, the opposite effect is almost a greater worry (i.e., that of lack of senescence and uncontrolled growth).

Whilst 'immortality' is the desirable property of a stem cell, there is a coincident risk of tumorigenicity with uncontrolled cell division. Transformations and an altered karyotype are always a concern, particularly following longterm culture. Culture expansion, especially of autologous cells, may be needed to obtain adequate numbers of cells for implantation. Hence it is very important to continually monitor any changes in the cell populations, but it is also very important to be sure of the results. There have been reports in the literature concerning the biosafety of MSCs. For example, Rosland et al. reported that there were spontaneous malignant transformations in $46 \%$ of cultures of human MSCs grown for 5-105 weeks, together with increased proliferation rates, altered cell morphologies and tumorogenic properties [133]. More recently, however, this paper has been retracted by the authors saying that these erroneous results were due to contamination by cell lines [134]. It appears that carefully controlling the culture conditions of MSCs can minimize their potential for malignant transformation [135]. Indeed Tarte et al. reported that whilst they found aneuploidy in some culture-expanded human MSC populations, this was not associated with transformations, rather the cells became senescent and growth arrested [136]. Very careful monitoring of all cells in all centers is very important, so that warning of aberrant phenotypes is monitored, yet without the risk of halting all progress due to 'scare mongering' [137].

Likewise careful monitoring of clinical trials involving stem cells should be undertaken worldwide. A recent report on a large number of patients who were injected with culture-expanded MSCs into peripheral joints $(n=213)$ or intervertebral discs $(n=13)$ have been followed for up to 2 years and show no neoplastic complications at any stem cell injection site [100]. These results are reassuring. However, there are reports from other areas of health using stem cells in the clinic that cause 
some concern for reasons other than tumorogenicity. Several trials of MSCs or bone marrowderived mononuclear cells have been undertaken in patients with spinal cord injuries (reviewed by Wright et al. [138]). Some results are encouraging but there is also reason for caution. A recent casecontrol trial of MSCs being injected intrathecally in chronic spinal cord injury patients resulted in adverse effects of neuropathic pain in 24 of the 43 patients given cells compared with none of the control population [139]. Therefore, it is vitally important that the correct and appropriate type of repair or regeneration is achieved.

The capability of stem cells to differentiate into many different cell types is a double-edged sword. Whilst it offers the opportunity to generate all tissue types, the fine control of this process is important. MSCs may have advantages over other stem cells in this manner if they are 'lineage primed' and have restrictions on the pathways down which they can travel and their degree of plasticity. For example, Delorme et al. demonstrated that bone marrow MSCs are primed for, and can differentiate down, osteoblastic, chondrocytic or adipogenic pathways but not myogenic, neural or hematopoetic [140].

There are also other possible safety concerns regarding cell therapy, particularly if autologous cells and serum for culture are not used throughout the process. For example, if allograft or xenograft cells or tissue are used as the donor material, they can add to the risk of disease transmission. Additional risks from animal diseases, for example bovine spongiform encephalitis, also arise even from autologous cells being cultured in vitro for expansion purposes, if they are grown in bovine serum. (Some centers, for ACI, grow the autologous cells in autologous serum to avoid this risk, but it requires considerable amounts of blood to be provided by the patient in the first instance and it may hamper consistency of cellular product due to interindividual variability of autologous serum.) ESCs, whilst of human origin, are often grown on a murine layer of feeder cells, again exposing the transplanted cells to animal pathogens, and increasing the risk of transmission of animal pathogens. The development of defined culture medium and feeder-free conditions [141], however, will reduce this risk area.

In addition to their use as a direct therapy, stem cells also provide an opportunity for studying the basic disease mechanisms of arthritis and joint disorders, and also to establish screens for drug discovery. The drug industry is now using stem cells to screen for drugs in other areas of medicine [142]. They could possibly be used as an in vitro clinical trial, by creating iPS cells from many individuals to predict a population response to a drug. This utilization may lead to as many improvements in treatment of the arthritic patient in the long term as the direct application of stem cells to the diseased joint.

One thing is certain: there is enough suffering caused in the human race by degenerative joint diseases such as OA to make patients keen to test any treatment that can result in alleviating the pain and disability. However, there is a problem in balancing the expectations of society with what can realistically be delivered, particularly with the sometimes overblown 'hype' in the western media.

\section{Conclusion}

The two principle characteristics of stem cells (i.e., the ability to self-renew and to differentiate along multiple lineages) make them an attractive option to treat age-related disorders that involve more than one tissue, such as degenerative joint diseases and arthritis. MSCs, with their potential influence on modulating the immune system, present themselves as an interesting choice, particularly when those arthritides have an inflammatory component. Adult MSCs are readily available from the patient, making this approach particularly attractive in terms of translation from bench to bedside. It is to be hoped that by improving our knowledge we can learn how to tailor natural factors within the joint, for example, encouraging MSCs to secrete paracrine factors that will create the optimum environment and drive it down a controlled reparative pathway [143]. A biological treatment (perhaps combined with other modalities) would certainly be advantageous in providing a treatment for early arthritis to prevent or slow disease progression, thus redefining the patient population that would benefit from joint replacement with its limited and finite lifespan.

\section{Future perspective}

Unlike many other areas of medicine, tissue engineering has already been used in the orthopedic clinic for several years. Therefore it should be well placed to capitalize on new understandings that come from the laboratory to improve on delivery of cellular therapies to the patient. Significant limitations of most current cell therapies for cartilage or bone repair are that they utilize autologous cells and require a two-stage procedure, which is costly both in terms of finance and logistics. Development of a source of 'universal donor cells' would be a great step forward, leading to a potential 'off-the-shelf' cellular product, 
making such a therapy much cheaper, easier to be developed by more clinicians and more widely available to a greater number of patients.

A further development it is hoped will be realized in the relatively near future is a more sophisticated characterization of cellular products, whether chondrocytes, MSCs or other stem cells, with an approach more akin to that seen in the pharmaceutical industry. However, it is never likely to be able to be controlled to the same extent as a chemical, since it is, by definition, a biological product with all the variability and versatility that it brings. It is important that this is recognized by the regulatory authorities, otherwise there is a danger that the development of cellular therapies will be delayed or stopped altogether by overzealous regulation.

Better understanding of the science of stem cells could actually negate the need for the addition of exogenous cells, as it could allow the development of ways to activate and control endogenous stem cells that are resident in their niche in vivo. Then they could direct the repair and regeneration of the osteoarthritic joint. The progress made in this direction in animal studies [77] suggests that within a decade a real biological solution may become available, particularly for the younger patient, where the regenerative capacity is likely to be good and the time taken to produce new tissue worth the investment. A scaffold impregnated with growth factors or signaling molecules could orchestrate different endogenous stem cell populations to effect appropriate repair and regeneration in a disease such as OA, involving as it does, several different tissue types.

\section{Acknowledgement}

The authors would like to thank Elen Bray, University of York, UK, for the adaptation of Figure 3.

\section{Financial \& competing interests disclosure}

The authors are grateful to support from Arthritis Research UK (Ref 18480 [S Roberts] and Ref 19271 [C De Bari]) and the European Commission's 7th Framework Programme (FP7, 2007-2013) under grant agreement no. HEALTH-F2-2008-201626 (Genodisc; S Roberts). $C D e$ Bari is a Fellow of the Medical Research Council, UK (MRC grant G108/620). The authors have no other relevant affiliations or financial involvement with any organization or entity with a financial interest in or financial conflict with the subject matter or materials discussed in the manuscript apart from those disclosed.

No writing assistance was utilized in the production of this manuscript.

\section{Executive summary}

\section{Osteoarthritis}

" Osteoarthritis (OA) is a common disorder involving damage to joint tissues, particularly cartilage and bone, but there can also be a component of attempted repair, albeit an aberrant one.

- Current treatments are mostly targeted at end-stage disease but biological therapies show promise for earlier intervention with a more prolonged benefit.

\section{Stem cells}

- Embryonic, fetal and adult tissue stem cells have varying degrees of differentiation potential and different advantages and disadvantages for cell therapies.

- Mesenchymal stem cells (MSCs) are defined by a series of 'markers' (although none are specific) and the ability to differentiate into several different mesenchymal tissue types, many of which are affected in OA.

\section{Endogenous joint stem cell niches}

- Regeneration of joint tissues is uncommon, but can occur rarely, suggesting the presence of stem cell niches within joints.

" MSC-like cells have been identified in synovial membrane, periosteum, bone marrow and synovial fluid, and progenitor/stem cells in articular cartilage.

\section{Cell therapy with exogenous stem cells}

- Autologous chondrocytes, which have been culture expanded, and more recently MSCs, have been used in the orthopedic clinic for nearly two decades.

- The use of a universal donor cell would rationalize the technique, likely making it much more widely used as a cell therapy.

\section{Bioprocessing \& regulatory aspects}

" A significant issue in cell therapy relates to standardization of the bioprocessing to ensure consistent cellular products linked to predictable structural and clinical outcomes.

- The regulatory authority for control of biological medicinal products is the European Medicines Agency (EMA), with regulations relating to stem cells evolving alongside their science and experience of their use in the clinic.

\section{Hopes \& fears of stem cells in the treatment of $O A$}

- Biological repair utilizing stem cells, whether they are introduced or resident within the host, offers considerable hope for a permanent regeneration of joint tissues that have been destroyed in degenerative joint diseases such as OA.

- However, needless to say there are many aspects, such as controlling differentiation and proliferation, which remain poorly understood and a cause of potential concern. 


\section{Bibliography}

Papers of special note have been highlighted as:

- of interest

" $"$ of considerable interest

1 Schroeppel JP, Crist JD, Anderson HC, Wang J: Molecular regulation of articular chondrocyte function and its significance in osteoarthritis. Histol. Histopathol. 26(3), 377-394 (2011).

2 Sun HB: Mechanical loading, cartilage degradation, and arthritis. Ann. NYAcad. Sci. 1211, 37-50 (2010).

3 Goldring SR, Goldring MB: Bone and cartilage in osteoarthritis: is what's best for one good or bad for the other? Arthritis Res. Ther. 12, 143 (2011).

4 Evangelou E, Valdes AM, Kerkhof HJ, Styrkarsdottir U, Zhu Y, Meulenbelt I: Meta-analysis of genome-wide association studies confirms a susceptibility locus for knee osteoarthritis on chromosome 7q22. Ann. Rheum. Dis. 70, 349-355 (2011).

5 Malchau H, Herberts P, Garellick G, Soderman P, Eisler T: Prognosis of total hip replacement: update of results and risk-ratio analysis for revision and re-revision from the Swedish National Hip Arthoplasty Register 1979-2000. Scientific Exhibition. Presented at: 69th Annual Meeting of the American Academy of Orthopaedic Surgeons. Dallas, TX, USA, 11-15 June 2002.

6 Chen FH, Tuan RS: Mesenchymal stem cells in arthritic diseases. Arthritis Res. Ther. $10(5), 223$ (2008).

7 Johnson $\mathrm{MH}, \mathrm{McC}$ Connell JM: Lineage allocation and cell polarity during mouse embryogenesis. Sem. Cell Dev. Biol. 15(5), 583-597 (2004).

8 Evans MJ, Kaufman MH: Establishment in culture of pluripotent cells from mouse embryos. Nature 292(5819), 154-156 (1981).

9 Martin GR: Isolation of a pluripotent cell line from early mouse embryos cultured in medium conditioned by teratocarcinoma stem cells. Proc. Natl Acad. Sci. USA 78(12), 7634-7638 (1981).

10 Bongso A, Fong CY, Ng SC, Ratnam S: Isolation and culture of inner cell mass cells from human blastocytes. Hum. Reprod. 9(11), 2110-2117 (1994).

11 Thomson JA, Itskovitz-Eldor J, Shapiro SS et al.: Embryonic stem cell lines derived from human blastocytes. Science 282(5391), 1145-1147 (1998).

12 Nichols J, Zevnik B, Anastassiadis K et al.: Formation of pluripotent stem cells in the mammalian embryo depends on the POU transcription factor Oct4. Cell 95(3), 379-391 (1998).
13 Chambers I, Colby D, Robertson M et al.: Functional expression cloning of Nanog, a pluripotency sustaining factor in embryonic stem cells. Cell 113(5), 643-655 (2003).

14 Rodda DJ, Chew JL, Lim LH et al.: Transcriptional regulation of nanog by OCT4 and SOX2. J. Biol. Chem. 280(26), 2473124737 (2005).

15 Johansson H, Simonsson S: Core transcription factors, Oct4 Sox 2 and Nanog, individually form complexes with nucleophosmin (Npm1) to control embryonic stem (ES) cell fate determination. Aging 2(11), 1-8 (2010).

16 Boyer LA, Plath K, Zeitlinger J et al.: Polycomb complexes repress developmental regulators in murine embryonic stem cells. Nature 441(7091), 349-353 (2006).

17 Lee JH, Hart SR, Skalnik DG: Histone deacetylase activity is required for embryonic stem cell differentiation. Genesis 38(1), 32-38 (2004).

18 Meshorer E, Misteli T: Chromatin in pluripotent embryonic stem cells and differentiation. Nat. Rev. Mol. Cell Biol. 7(7), 540-546 (2006).

19 Efroni S, Duttagupta R, Cheng J et al.: Global transcription in pluripotent embryonic stem cells. Cell Stem Cell 2(5), 437-447 (2008).

20 Houbaviy HB, Murray MF, Sharp PA: Embryonic stem cell-specific microRNAs. Dev. Cell 5(2), 351-358 (2003).

21 Kanellopoulou C, Muljo SA, Kung AL et al.: Dicer-deficient mouse embryonic stem cells are defective in differentiation and centromeric silencing. Genes Dev. 19(4), 489-501 (2010).

22 Kim NW, Piatyszek MA, Prowse KR et al.: Specific association of human telomerase activity with immortal cells and cancer. Science 266(5193), 2011-2015 (1994).

23 Miura T, Mattson MP, Roa MS: Cellular lifespan and senescence signaling in embryonic stem cells. Aging Cell 3(6), 333-343 (2010).

24 Zhong XY, Zhang B, Asadollahi R, Low SH, Holzgreve W: Umbilical blood stem cells: what to expect. Ann. NY Acad. Sci. 1205, 17-22 (2010).

25 Gluckman E, Broxmeyer HA, Auerbach AD et al.: Hematopoietic reconstruction in a patient with Fanconi's anemia by means of umilical-cord blood from an HLA-identical sibling. N. Engl. J. Med. 321(17), 1174-1178 (1989).

26 Quintin A, Schizas C, Scaletta C et al.: Isolation and in vitro chondrogenic potential of human fetal spine cells. J. Cell. Mol. Med. 13, 2559-2569 (2009).

27 O'Donoghue K, Fisk NM: Fetal stem cells. Best Pract. Res. Clin. Obstet. Gynaecol. 18(6), 853-875 (2004).
28 Gucciardo L, Lories R,

Ochsenbein-Kolble N, Done E, Zwijsen A, Deprest J: Fetal mesenchymal stem cells: isolation, properties and potential use in perinatology and regenerative medicine. Br. J. Obstet. Gynaecol. 116(2), 166-172 (2009).

29 Pappa KL, Anganou NP: Novel sources of fetal stem cells: where do they fit on the deveopmental continuum? Regen. Med. 4(3), 423-433 (2009).

30 Kita K, Gauglitz GG, Phan TT, Herndon DN, Jeschke MG: Isolation and characterization of mesenchymal stem cells from the sub-amniotic human ubilical lining membrane. Stem Cells Dev. 19(4), 491-502 (2010).

31 Takahashi K, Yamanaka S: Induction of pluripotent stem cells from mouse embryonic and adult fibroblast cultures by defined factors. Cell 126(4), 663-676 (2006).

"I- Landmark paper that demonstrated for the first time that adult cells could be reprogrammed to a pluripotent embryonic stem cell-like state by introducing as few as four key transcription factors.

32 Takahashi K, Tanabe K, Ohnuki M et al.: Induction of pluripotent stem cells from adult human fibroblasts by defined factors. Cell 131(5), 861-872 (2007).

33 Wernig M, Meissner A, Foreman R et al.: In vitro reprogramming of fibroblasts into a pluripotent ES-cell-like state. Nature 448(7151), 318-324 (2007).

34 Yu J, Vodyanik MA, Smuga-Otto K et al.: Induced pluripotent stem cell lines derived from human somatic cells. Science 318(5858), 1917-1920 (2007).

35 Kim K, Doi A, Wen B: Epigenetic memory in induced pluripotent stem cellls. Nature 467(7313), 285-290 (2010).

36 Pasi CE, Dedreli-Oz A, Negrini S et al.: Genomic instability in induced stem cells. Cell Death Diff. 18(5), 745-753 (2011).

37 Huangfu D, Osafune K, Maehr R et al.: Induction of pluripotent stem cells from primary human fibroblasts with only Oct4 and Sox2. Nat. Biotechnol. 26(11), 1269-1275 (2008).

38 Woltjen K, Michale IP, Mohseni P et al.: A piggyBac transposition reprograms fibroblasts to induced pluripotent stem cells. Nature 458(7239), 766-770 (2009).

39 Kaji K, Norrby K, Paca A, Mileikovsky M, Mohseni P, Woltjen K: Virus-free induction of pluripotency and subsequent excision of reprogramming factors. Nature 458(7239), 771-775 (2009). 
40 Nakagawa M, Takizawa N, Narita M, Ichisaka T, Yamanaka S: Promotion of direct reprogramming by transformation-deficient Myc. Proc. Natl Acad. Sci. USA 107(32), 14152-14157 (2010).

41 Flores I, Blasco MA: The role of telomeres and telomerase in stem cell aging. Fed. Eur. Biochem. Soc. Lett. 584(17), 3826-3830 (2010).

42 Scadden DT: The stem cell niche as an entity of action. Nature 441(7097), 1075-1079 (2006).

43 Friedenstein AJ, Chailakhjan RK, Lalykina KS: The development of fibroblast colonies in monolayer cultures of guinea-pig bone marrow and spleen cells. Cell Tissue Res. 3(4), 393-403 (1970).

"- Colony formation identified as an important indicator of 'stem cell-ness'.

44 Caplan AI: Mesenchymal stem cells. J. Orthop. Res. 9(5), 641-650 (1991).

45 Horwitz EM, Le Blanc K, Dominici M et al.: Clarification of the nomenclature for MSC: the International Society for Cellular Therapy position statement. Cytotherapy 7(5), 393-395 (2005).

46 Bianco P, Robey PG, Saggio I, Riminucci M: Mesenchymal stem cells in human bone marrow (skeletal stem cells): a critical discussion of their nature, identity and significance in incurable skeletal disease. Hum. Gene Ther. 21(9), 1057-1066 (2010).

47 da Silva ML, Chagatelles PC, Nardi NB: Mesenchymal stem cells reside in virtually all post-natal organs and tissues. J. Cell Sci. 119(11), 2204-2213 (2006).

48 Pittenger MF, Mackay AM, Beck SC et al.: Multilineage potential of human mesenchymal stem cells. Science 284, 143-147 (1999).

- Provides evidence of existence of multipotent mesenchymal stem cells (MSCs) in bone marrow.

49 Dominici M, Le Blanc K, Mueller I et al.: Minimal criteria for defining multipotent mesenchymal stromal cells. The International Society for Cellular position statement. Cytotherapy 8(4), 315-317 (2006).

50 Simmons PJ, Torok-Storb B: Identification of stromal cell precursors in human bone marrow by a novel monoclonal antibody, STRO-1. Blood 78(1), 55-62 (1991).

51 Jones EA, Kinsey SE, English A et al.: Isolation and characterization of bone marrow multipotential mesenchymal progenitor cells. Arthritis Rheum. 46(12), 3349-3360 (2002).

52 Sacchetti B, Funari A, Michienzi $S$ et al.: Self-renewing osteoprogenitors in bone marrow sinusoids can organise a hematopoietic microenvironment. Cell 131(2), 324-336 (2007).
" Provides first evidence of self-renewal of bone marrow MSCs via serial transplantation.

53 Barzilay R, Melamed E, Offen D: Introducing transcription factors to multipotent mesenchymal stem cells: making transdifferentiation possible. Stem Cells 27(10), 2590-2515 (2009).

54 Frith J, Genever P: Transcriptional control of mesenchymal stem cell differentiation. Transf. Med. Hemother. 35(3), 216-227 (2008).

55 Jaiswal N, Haynesworth SE, Caplan AI, Bruder SP: Osteogenic differentiation of purified, culture-expanded human mesenchymal stem cells in vitro. J. Cell. Biochem. 64(2), 295-312 (1997).

56 de Crombrugghe B, Lefebvre V, Behringer RR, Bi W, Murakami S, Huang W: Transcriptional mechanisms of chondrocyte differentiation. Matrix Biol. 19, 389-394 (2000).

57 Zhou G, Zheng Q, Engin F et al:: Dominance of SOX9 function over RUNX2 during skeletogenesis. Proc. Natl Acad. Sci. USA 103(50), 19004-19009 (2006).

58 Cheng A, Genever PG: SOX9 determines RUNX transactivity by directing intracellular degradation. J. Miner. Res. 25(12), 2404-2413 (2010).

59 Si YL, Zhao YL, Hao HJ, Fu XB, Han WD: MSCs: biological characteristics, clinical applications and their outstanding concerns. Ageing Res. Rev. 10(1), 93-103 (2011).

60 Hoogduijn MJ, Popp F, Verbeek R et al.: The immunomodulatory properties of mesenchymal stem cells and their use for immunotherapy. Int. Immunopharmacol. 10(12), 1496-1500 (2010).

61 Liu Y, Mu R, Wang S et al.: Therapeutic potential of human umbilical cord mesenchymal stem cells in the treatment of rheumatoid arthritis. Arthritis Res. Ther. 12(6), R210 (2010).

62 Di Nicola M, Carlo-Stella C, Magni M et al.: Human bone marrow stromal cells suppress T-lymphocyte proliferation induced by cellular or nonspecific mitogenic stimuli. Blood 99 , 3838-3843 (2002).

63 Popp FC, Eggenhofer E, Renner P et al.: Mesenchymal stem cells can induce long-term acceptance of solid organ allografts in synergy with low-dose mycophenolate. Transplant Immunol. 20, 55-60 (2008).

64 Bartholomew A, Sturgeon C, Siatskas M et al:: Mesenchymal stem cells suppress lymphocyte proliferation in vitro and prolong skin graft survival in vivo. Exp. Haematol. 30, 42-48 (2002).

65 Aggarwal S, Pittenger MF: Human mesenchymal stem cells modulate allogeneic immune cell responses. Blood 105, 1815-1822 (2005).
66 Yao C, Sakata D, Esaki Y et al.: Prostaglandin E2-EP4 signaling promotes immune inflammation through Th1 cell differentiation and Th17 cell expansion. Nat. Med. 15, 633-640 (2009).

67 Yanez R, Oviedo A, Aldea M, Bueren JA, Lamana ML: Prostaglandin E2 plays a key role in the immunosuppressive properties of adipose and bone marrow tissue-derived mesenchymal stromal cells. Exp. Cell Res. 316, 3109-3123 (2010).

68 Sbano P, Cuccia A, Mazzanti B et al.: Use of donor bone marrow mesenchymal stem cells for treatment of skin allograft rejection in a preclinical rat model. Arch. Dermatol. Res. 300(3), 115-124 (2008).

69 Mias C, Lairez O, Trouche E et al.: Mesenchymal stem cells promote matrix metalloproteinase secretion by cardiac fibroblasts and reduce cardiac ventricle fibrosis after myocardial infarction. Stem Cells 27(11), 2734-2743 (2009).

70 Yagi H, Soto-Guitierrez A, Parekkadan B et al.: Mesenchymal stem cells: mechanisms of immunomodulation and homing. Cell Transplant. 19(6), 667-679 (2010).

71 Chamberlain G, Fox J, Ashton B, Middleton J: Concise review: mesenchymal stem cells: their phenotype, differentiation capacity, immunological features, and potential for homing. Stem Cells 25, 2739-2749 (2007).

72 Ding C, Cicuttini F, Cooley H, Boon C, Jones G: Natural history of knee cartilage defects and factors affecting change. Arch. Int. Med. 166(6), 651-658 (2006).

73 Messner K, Maletius W: The long-term prognosis for severe damage to weightbearing cartilage in the knee: a 14 year clinical and radiographic follow-up in 28 young athletes. Acta Orthop. Scand. 67(2), 165-168 (1996).

74 Shelbourne KD, Jari S, Gray T: Outcome of untreated traumatic articular cartilage defects of the knee: a natural history study. J. Bone Joint Surg. Am. 85A(Suppl. 2), 8-16 (2003).

75 Shapiro F, Koide S, Glimcher MJ: Cell origin and differentiation in the repair of fullthickness defects of articular cartilage. J. Bone Joint Surg. Am. 75A(4), 532-553 (1993).

76 Eltawil NM, De Bari C, Achan P, Pitzalis C, Dell'Accio F: A novel in vivo murine model of cartilage regeneration. Age and strain-dependent outcome after joint surface injury. Osteoarthritis Cart. 17(6), 695-704 (2009).

77 Lee CH, Cook JL, Mendelson A, Moioli EK, Yao H, Mao JJ: Regeneration of the articular surface of the rabbit synovial joint by cell homing: a proof of concept study. Lancet 7(376), 440-448 (2010). 
78 Jones EA, English A, Henshaw K et al.: Enumeration and phenotypic characterization of synovial fluid multipotential mesenchymal stem cells in inflammatory and degenerative arthritis. Arthritis Rheum. 50(3), 315-317 (2004).

79 De Bari C, Dell'Accio F, Tylzanowski P, Luyten FP: Multipotent mesenchymal stem cells from adult human synovial membrane. Arthritis Rheum. 44(8), 1928-1942 (2001).

80 De Bari C, Dell'Accio F, Vandenabeele F, Vermeesch JR, Raymackers JM, Luyten F: Skeletal muscle repair by adult human mesenchymal stem cells from synovial membrane. J. Cell Biol. 160(6), 909-918 (2003).

81 De Bari C, Dell'Accio F, Luyten F: Human periosteum-derived cells maintain phenotypic stability and chondrogenic potential throughout expansion regardless of donor age. Arthritis Rheum. 44(1), 85-95 (2001).

82 De Bari C, Dell'Accio F, Vanlauwe J et al.: Mesenchymal multipotency of adult human periosteal cells demonstrated by single-cell lineage analysis. Arthritis Rheum. 54(4), 1209-1221 (2006).

83 Nakahara H, Dennis JE, Bruder SP, Haynesworth SE, Lennon DP, Caplan A: In vitro differentiation of bone and hypertrophic cartilage from periostealderived cells. Exp. Cell Res. 195, 492-503 (1991).

84 Sakai D: Biological treatment: future beyond cell transplantation. Proc. World Forum Spine Res. (2010) (Epub ahead of print).

85 Zuk PA, Zhu M, Ashjian P et al: Human adipose tissue is a source of multipotent stem cells. Mol. Biol. Cell 13, 4279-4295 (2002).

86 Dowthwaite GP, Bishop JC, Redman SN et al.: The surface of articular cartilage contains a progenitor cell population. J. Cell Sci. 117, 889-897 (2004).

87 Williams R, Khan IM, Richardson K et al.: Identification and clonal characterisation of a progenitor cell sub-population in normal human articular cartilage. PLoS One 5(10), 1-14 (2010)

88 Shi S, Gronthos S: Perivascular niche of postnatal mesenchymal stem cells in human bone marrow and dental pulp. J. Bone Miner. Res. 18(4), 696-704 (2003).

89 De Bari C, Pringle S, Pitzalis C, Dell'Accio F: The stem cell niche: a new target in medicine. Curr. Opin. Orthop. 17(5), 398-404 (2006).

90 da Silva ML, Caplan AI, Nardi NB: In search of the in vivo identity of mesenchymal stem cells. Stem Cells 26(9), 2287-2299 (2008).
91 Khan IM, Bishop JC, Gilbert S, Archer CW: Clonal chondroprogenitors maintain telomerase activity and Sox 9 expression during extended monolayer culture and retain chondrogenic potential. Osteoarthritis Cart. 17, 518-528 (2009).

92 Koelling S, Krugel J, Irmer M et al.: Migratory chondrogenic progenitor cells from repair tissue during the later stages of human osteoarthritis. Cell Stem Cell 4(4), 324-335 (2009).

93 Koelling S, Miosge N: Sex differences of chondrogenic progenitor cells in late stages of osteoarthritis. Arthritis Rheum. 62(4), 1077-1087 (2010).

94 English A, Jones EA, Corscadden D et al.: A comparative assessment of cartilage and joint fat pad as a potential source of cells for autologous therapy development in knee osteoarthritis. Rheumatology 46, 1676-1683 (2007).

95 Yarak S, Okamoto OK: Human adiposederived stem cells: current challenges and clinical perspectives. An. Bras. Dermatol. 85(5), 647-656 (2010).

96 Kurth TB, Dell'Accio F, Crouch V, Augello A, Sharpe PT, De Bari C: Functional mesenchymal stem cell niches in the adult knee joint synovium in vivo. Arthritis Rheum. (2010) (Epub ahead of print).

- Provides first evidence of existence of endogenous MSCs in the adult synovium in vivo.

97 Brittberg M, Lindahl A, Nilsson A, Ohlsson C, Isaksson O, Peterson L: Treatment of deep cartilage defects in the knee with autologous chondrocyte transplantation. N. Engl. J. Med. 331(6), 889-895 (1994).

98 Meisel HJ, Siodla V, Ganey T, Minkus Y, Hutton WC, Alasevic O: Clinical experience in cell-based therapeutics: disc chondrocyte transplantation - a treatment for degenerated or damaged intervertebral disc. Biomol. Eng. 24, 5-21 (2006).

99 Bajada S, Harrison PE, Ashton BA, Cassar-Pullicino VN, Ashammakhi N, Richardson JB: Successful treatment of refactory tibial nonunion using calcium sulphate and bone marrow stromal cell implantation. J. Bone Joint Surg. Br. 89, 1382-1386 (2007).

100 Centeno CJ, Schultz JR, Cheever M, Robinson B, Freeman M, Marasco W: Safety and compliations reporting on the reimplantation of culture-expanded mesenchymal stem cells using autologous platelet lysate technique. Curr. Stem Cell Res. Ther. 5, 81-93 (2010).

101 Bhosale A, Kuiper JH, Johnson WEB, Harrison P, Richardson JB: Midterm to long-term longitudinal outcome of autologous chondrocyte implantation in the knee joint - a multilevel analysis. Am. J. Sports Med. 20(10), 1-8 (2009).

102 Hollander AP, Dickinson SC, Sims TJ, Soranzo C, Pavesio A: Quantitative analysis of repair tissue biopsies following chondrocyte implantation. Tissue Eng. Cart. Bone 249, 218-233 (2003).

103 Haddo O, Mahroof S, Higgs D et al.: The use of chondrogide membrane in autologous chondrocyte implantation. Knee 11, 51-55 (2004).

104 Zheng M-H, Willers C, Kirilak L et al.: Matrix-induced autologous chondrocyte implantation (MACI): biological and histological assessment. Tissue Eng. 13(4), 737-746 (2007).

105 Kreuz PC, Muller S, Ossendorf C, Kaps C, Erggelet C: Treatment of focal degenerative cartilage defects with polymer-based autologous chondrocyte grafts: four-year clinical results. Arthritis Res. Ther. 11(2), R33 (2009).

106 Warnke PH, Springer ING, Wiltfang J et al. Growth and transplantation of a custom vascularised bone graft in a man. Lancet 364, 766-769 (2005).

107 Macchiarini M, Jungebluth P, Go T et al.: Clinical transplantation of a tissueengineered airway. Lancet 372(9655), 2023-2030 (2008).

108 De Bari C, Pitzalis C, Dell'Accio F: Reparative medicine: from tissue engineering to joint surface regeneration. Regen. Med. 1(1), 59-69 (2006).

109 Dell'Accio F, De Bari C, Luyten FP: Molecular markers predictive of the capacity of expanded human articular chondrocytes to form stable cartilage in vivo. Arthritis Rheum. 44(7), 1608-2619 (2001).

- Proposes an in vivo potency assay for chondrocyte preparations to be used for autologous chondrocyte implantation and links its outcome to molecular markers.

110 Roberts S, Hollander AP, Caterson B, Menage J, Richardson JB: Matrix turnover in human cartilage repair tissue in autologous chondrocyte implantation. Arthritis Rheum. 44, 2586-2598 (2001).

111 Saris DBF, Vanlauwe J, Victor J et al.: Characterized chondrocyte implantation results in better structural repair when treating symptomatic cartilage defects of the knee in a randomized controlled trial versus microfracture. Am. J. Sports Med. 36(2), 235-246 (2008).

112 Saris DB, Vanlauwe J, Victor J et al.: Treatment of symptomatic cartilage defects of the knee: characterized chondrocyte implantation results in better clinical outcome 
at 36 months in a randomized trial compared with microfracture. Am. J. Sports Med. 37(Suppl. 1), 10S-19S (2009).

113 Tyndall A, Walker UA, Cope A et al: Immunomodulatory properties of mesenchymal stem cells: a review based on an interdisciplinary meeting held at the Kennedy Institute of Rheumatology Division, London, UK, 31 October 2005. Arthritis Res. Ther. 9(1), 301 (2007).

114 Wakitani S, Imoto K, Yamamoto T, Saito M, Murata N, Yoneda M: Human autologous culture expanded bone marrow mesenchymal cell transplantation for repair of cartilage defects in osteoarthritic knees. Osteoarthritis Cart. 10, 199-206 (2002).

115 De Bari C, Dell'Accio F, Luyten F: Failure of in vitro-differentiated mesenchymal stem cells from the synovial membrane to form ectopic stable cartilage in vivo. Arthritis Rheum. 50(1), 142-150 (2004).

116 Scotti C, Tonnarelli B, Papadimitropoulos A et al:: Recapitulation of endochondral bone formation using human adult mesenchymal stem cells as a paradigm for developmental engineering. Proc. Natl Acad. Sci. USA 107(16), 7251-7256 (2010).

- Provides evidence that bone marrow MSCs can recapitulate endochondral ossification morphologically and molecularly.

117 Pelttari K, Winter A, Steck E et al:: Premature induction of hypertrophy during in vitro chondrogenesis of human mesenchymal stem cells correlates with calcification and vascular invasion after ectopic transplantation in SCID mice. Arthritis Rheum. 54(10), 3254-3266 (2006).

118 De Bari C, Dell'Accio F, Karystinou A et al.: A biomarker-based mathematical model to predict bone-formation potency of human synovial and periostoeal mesenchymal stem cells. Arthritis Rheum. 58(1), 240-250 (2008).

119 Sakaguchi Y, Sekiya I, Yagishita K, Muneta T: Comparison of human stem cells derived from various mesenchymal tissues: superiority of synovium as a cell source. Arthritis Rheum. 52(8), 2521-2529 (2005).

120 Karystinou A, Dell'Accio F, Kurth TB et al.: Distinict mesenchymal progenitor cell subsets in the adult human synovium. Rheumatology 48(9), 1057-1064 (2009).

121 Fickert S, Fiedler J, Brenner RE: Identification of subpopulations with characteristics of mesenchymal progenitor cells from human osteoarthritic cartilage using triple staining cell surface markers. Arthritis Res. Ther. 6(5), R422-R432 (2004).

122 Trommelmans L, Selling J, Dierickx K: A critical assessment of the directive on tissue engineering of the European Union. Tissue Eng. 13(4), 667-672 (2007).
123 Michaux G, Van Passel D: Advanced therapy medicinal products - the rules are harmonised in Europe. Reg. Affairs J. Pharma 18(8), 1-10 (2007).

124 Kent J, Pfeffer N: Regulating the collection and use of fetal stem cells. Br. Med. J. 332(7546), 866-867 (2006).

125 Barker M: Stem cells: fast and furious. Nature 458(7241), 962-965 (2009).

126 Evangelou E, Loughlin J, Spector TD: Meta-analysis of genome-wide association studies confirms a susceptibility locus for knee osteosrthritis on chromosome 7q22. Ann. Rheum. Dis. 70 (2), 349-355 (2011).

127 Meulenbelt I, Bos SD, Chapman K et al:: Meta-analysis of genes modulating intracellular T3 bio-availability reveal a possible role for the $\mathrm{DIO}_{3}$ gene in osteoarthritis susceptibility. Br. Med.J. 70(1), 164-167 (2011).

128 Sambrook PN, MacGregor AJ, Spector TD: Genetic influences on cervical and lumbar disc degeneration: a magnetic resonance imaging study in twins. Arthritis Rheum. 42(2), 366-372 (1999).

129 Videman T, Battié MC, Ripatti S, Gill K, Manninen H, Kaprio J: Determinants of the progression in lumbar degeneration: a 5 year follow-up study of adult male monozygotic twins. Spine 31(6), 671-678 (2006).

130 Bajada S, Marshall MJ, Wright KT, Richardson JB, Johnson WEB: Decreased osteogenesis, increased cell senescence and elevated Dickkopf-1 secretion in human fracture non union stromal cells. Bone 45, 726-735 (2010).

131 Stenderup K, Justesen J, Clauusen C, Kassem M: Aging is associated with decreased maximal life span and accelerated senescence of bone marrow stromal cells. Bone 33, 919-926 (2003).

132 Murphy JM, Dixon K, Beck S, Fabian D, Feldman A, Barry F: Reduced chondrogenic and adipogenic activity of mesenchymal stem cells from patients with advanced osteoarthritis. Arthritis Rheum. 46(3), 704-713 (2002).

133 Røsland GV, Svendsen A, Torsvik A et al.: Long-term cultures of bone marrow-derived human mesenchymal stem cells frequently undergo spontaneous malignant transformation. Cancer Res. 69(13), 5331-5339 (2009).

134 Torsvik A, Røsland GV, Svendsen A et al: Spontaneous malignant transformation of human mesenchymal stem cells reflects cross-contamination: putting the research field on track - letter. Cancer Res. 70(15), 6393-6396 (2010).
135 Prockop DJ, Brenner H, Fibbe WE et al.: Defining the risks of mesenchymal stromal cell therapy. Cytotherapy 12(5), 576-578 (2010).

136 Tarte K, Gaillard J, Lataillade JJ et al.: Clinical-grade production of human mesenchymal stromal cells: occurrence of aneuploidy without transformation. Blood 115(8), 1549-1553 (2010).

137 Rubio D, Garcia-Castro J, Martin MC et al:: Spontaneous human stem cell transformation. Cancer Res. 68(8), 3035-3039 (2005).

138 Wright K, El Masri W, Osman A, Chowdury J, Johnson WEB: Bone marrow cell therapy for SCI. Stem Cell Rev. (2010) (Epub ahead of print).

139 Kishk NA, Gabr H, Hamdy S et al.: Case control series of intrathecal autologous bone marrow mesenchymal stem cell therapy for chronic spinal cord injury. Neurorehabil. Neural Repair 24(8), 702-708 (2010).

140 Delorme B, Ringe J, Pontikoglou C et al.: Specific lineage-priming of bone marrow mesenchymal stem cells provides the molecular framework for their plasticity. Stem Cells 27, 1142-1151 (2009).

141 Oldershaw RA, Baxter MA, Lowe ET et al.: Directed differentiation of human embryonic stem cells towards chondrocytes. Nat. Biotechnol. 28(11), 1187-1196 (2010).

142 Barker M: Testing times for stem cells. Nature 463(7282), 719-719 (2010).

143 Caplan AI: Mesenchymal stem cells: the past, the present, the future. Cartilage 1(1), 6-9 (2010).

144 Caplan AI, Bruder SP: Mesenchymal stem cells: building blocks for molecular medicine in the 21st century. Trends Mol. Med. 7(6), 259-264 (2001).

\section{Websites}

201 Arthritis Care: OA Nation: the most comprehensive UK report of people with osteoarthritis www.arthritiscare.org.uk/@3235/ Forhealthprofessionals/OANation

202 The National Collaborating Centre for Chronic Conditions: Osteoarthritis. National clinical guideline for care and management in adults www.nice.org.uk/nicemedia/pdf/ CG59NICEguideline.pdf

203 European Medicines Agency CAT: Reflection paper on stem cell-based medicinal products www.ema.europa.eu/docs/en_GB/ document_library/Scientific_ guideline/2010/03/WC500079932.pdf 